\title{
UMA LEITURA ANTROPOLÓGICA DO CUR DEUS HOMO DE SANTO ANSELMO DE AOSTA
}

\author{
Manoel Vasconcellos ${ }^{1}$
}

\begin{abstract}
RESUMO: O presente estudo pretende analisar a obra Cur Deus homo, de Santo Anselmo, a partir de uma perspectiva antropológica. Após examinar a peculiaridade do método e revisar seus argumentos fundamentais, será possível perceber que Anselmo revela uma perspectiva essencialmente boa da natureza humana, que, mesmo abalada, nâo sucumbe ao pecado original. A liberdade e o projeto amoroso do Logos originante fundamentam a concepção anselmiana em torno do homem e sua natureza.
\end{abstract}

PALAVRAS-CHAVE: Homem. Liberdade. Pecado original.

\section{INTRODUÇÃo}

De que forma Anselmo de Aosta (1033-1109) compreende o homem? Um ser decaído, ingrato, encurvado sob o peso do pecado? Obra prima da criação, feito bom e para o bem? Nos escritos de Anselmo, podem ser localizadas passagens que ressaltam aspectos bons e maus da criatura humana. No entanto, é no Cur Deus homo, uma das mais extensas e complexas obras do Doutor Magnífico, que podemos encontrar a sua mais clara e genuína perspectiva antropológica. No presente estudo, intentamos mostrar que o homem que transparece na obra anselmiana é, essencialmente, bom, razão pela qual o pecado original, em que pese todas as vicissitudes que acarreta, não tem força suficiente para alterar a boa essência humana, mesmo que a tenha manchado.

Antes do Cur Deus homo, Anselmo compôs uma trilogia sobre a Sagrada Escritura. Os tratados - De Veritate, De Libertate Arbitrii e De casu diaboli - não são comentários bíblicos e, se foram unificados pelo seu autor, com base em um comum studium sacrae scripturae, é, certamente, porque partilham uma motivação bíblica, sobretudo o primeiro deles, o De Veritate, obra que estabelece as bases conceituais para o que será desenvolvido nos outros dois escritos. Os temas dessa trilogia são, de certa forma, retomados

\footnotetext{
${ }^{1}$ Professor do Departamento de Filosofia e do PPG Filosofia da Universidade Federal de Pelotas.
} 
no Cur Deus homo, a partir de um enfoque antropológico. Os conceitos de $v_{\text {verdade }}^{2}$ e justiça $a^{3}$ aliados à noção de retidão, apresentados no De Veritate, são importantes para a compreensão do dever-ser humano e da conciliação entre a justiça e a misericórdia divinas, tais como aparecem no Cur Deus homo; a liberdade, tema do De libertate arbitrii, se faz presente no Cur Deus homo, especialmente, para destacar náo apenas o caráter absolutamente isento de constrangimento que configura o sacrifício do verbo encarnado em favor da humanidade pecadora, mas também para evidenciar o caráter livre da criatura racional; também o instigante problema do mal, examinado em sua essência, por assim dizer, no De casu diaboli, tendo como foco o pecado dos anjos, é retomado, no Cur Deus homo, numa perspectiva antropológica.

Anselmo é e faz questão de ser um discípulo de Agostinho. O bispo de Hipona é, para ele, uma especial referência e autoridade. Ora, a preocupação em torno de Deus e do homem, revelada por Agostinho nos Solilóquios, é também o interesse fundamental de Anselmo, demonstrado desde o Monologion, seu primeiro tratado sistemático, uma obra que, de uma certa forma, anuncia e fundamenta muitos temas os quais serão retomados em escritos posteriores. É no Cur Deus homo, contudo, mais do que em qualquer outro texto de Anselmo, que homem e Deus recebem um tratamento minucioso, evidenciando o drama existencial do homem pecador, bem como a justiça e misericórdia divinas. Tais problemas serão examinados sola ratione, razão pela qual, antes de abordarmos as questôes internas do tratado, é necessário discorrer sobre sua peculiar metodologia.

\section{Consideraçóes Sobre o método}

O objetivo do Cur Deus homo é responder a uma questão que diz respeito à estrutura mais fundamental da religião cristã e que a diferencia dos demais monoteísmos: por qual razão e necessidade, afinal, Deus, que é onipotente, assumiu a frágil condição humana? A obra está dividida em duas grandes partes: na primeira, composta por vinte e cinco capítulos, são apresentadas as objeções dos chamados "infiéis", os quais julgam as concepções cristãs como contrárias à razão; além disso, há uma explanação sobre o modo como o cristianismo compreende a encarnação do verbo; nessa primeira parte, Anselmo pretende explicar por que a redenção da humanidade pecadora não

\footnotetext{
2 "Veritas est rectitudo mente sola perceptibilis" (DV 11, 191, 19-20).

3 "Iustitia igitur est rectitudo voluntatis propter se servata" (DV 12, 194, 26).
} 
poderia ter ocorrido de uma outra forma; na segunda parte, formada por vinte e dois capítulos, o autor expóe aquela que ficou conhecida como a "teoria anselmiana da satisfação", segundo a qual o pecado original fez surgir uma dívida que, se não for paga, torna impossível ao homem retomar a felicidade que lhe estava, desde sempre, destinada.

Sem dúvida, são questôes com forte apelo teológico e que já tinham sido objeto da consideração de importantes autores, tais como Atanásio, Irineu, Inácio de Antioquia, Justino e Agostinho, entre outros. Anselmo tem consciência disso, pois faz menção aos Padres, no texto da Commendatio, a carta em que apresenta a obra ao Papa Urbano II.

O Cur Deus homo é dirigido não só aos que não creem, mas também aos cristãos, os quais poderão alegrar-se pela compreensão, tanto quanto possível à razão humana, daquilo que é objeto da sua fé e da sua esperança. $\mathrm{O}$ autor reconhece a dificuldade de seu intento, uma vez que deseja utilizar a limitada razão humana para perscrutar os profundos mistérios da divindade. Por certo, o autor náo minimiza a grandiosidade e complexidade do objeto, no entanto, não se sente intimidado em empreender um esforço de compreensão racional da encarnação do verbo, acreditando ser possível chegar a um resultado satisfatório, o qual é precisamente uma compreensão acessível a sábios ou ignorantes, crentes ou não crentes. É perceptível o otimismo anselmiano quanto à capacidade da razão ${ }^{4}$ em perscrutar os conteúdos da fé. Nesse sentido, o Cur Deus homo não é de todo inédito, pois aquele mesmo método sola ratione, inaugurado no Monologion, é, agora, aplicado à encarnação do verbo, de modo que todos os argumentos deverão estruturar-se no encadeamento das razóes necessárias, as quais, por si mesmas, conduzem à clareza da verdade. O sola ratione do Monologion tomará a forma, no Cur Deus homo, do remoto christo: ainda que absolutamente nada soubéssemos sobre Jesus Cristo, isto

\footnotetext{
4 “[...] quando se fala das relações fé-razão, englobam-se inicialmente, sob a última denominação, aquelas capacidades do homem que the permitem relacionar e descobrir relaçóes, universalizar, abstrair, ter noçôes não sensoriais do que é sensorial, tentar definiçốes de totalidade, perguntar-se por seres imateriais acima do tempo e do espaço e dar uma resposta seja ela qual for, pôr-se finalmente o problema acerca de algo que nấo caiba nas categorias da realidade investigada, e acerca da sua relação com o resto se é que existe, acabando finalmente por reverter ao próprio interrogante. Quer se trate de uma actividade cognitiva buscadora ou construtora (ou desconstrutora), quer se trate de uma captaçáo de algo imediatamente, de forma não sensorial, uma e outra faceta dizem respeito à racionalidade: as duas célebres expressōes fides quaerens intellectum e crede ut intelligas representam que se procure um esclarecimento em que a análise discursiva de um sentido e da ausência de princípios que contrariem os princípios orientadores do conhecimento tem um nome: razão". (MACEDO, J.M. Costa. Anselmo e a Astúcia da Razão. Porto Alegre: EST, 2009, p. 253).
} 
é, prescindindo dos conhecimentos históricos, incluindo os conhecimentos advindos da fé, mesmo assim, seria possível concluir que o homem foi criado para um determinado fim, que só poderá ser alcançado através de um homemDeus, sem o qual a humanidade não poderá ser feliz. Como assinala Macedo (2009, p. 20), tal metodologia quer obter audazes conclusôes metafísicas, com base em um processo investigativo que não tem na fé o seu ponto de partida.

A fim de mostrar que há uma lógica da encarnação, Anselmo recorre às razôes necessárias. Elas significam que o esforço de argumentação, sendo correto, conduz à clarificação da verdade sem a necessidade do recurso a meios que extrapolem a argumentação em si mesma. A validade da argumentação deve estar nela mesma. Trata-se de um método de investigação inserido no contexto da discussão dialética, com o intuito de buscar a verdade, afastandose do erro. Náo ter em conta os dados que as Escrituras revelam sobre Jesus Cristo não implica negar a autoridade, seja das Escrituras, seja da tradição da Igreja. O que Anselmo deseja é trazer a discussão sobre a necessidade de um Deus-homem para um terreno comum a todos os homens, onde a força dos argumentos tenha condiçóes de demonstrar a razoabilidade da encarnação, sem precisar do amparo da autoridade para demonstrar sua validade. Assim sendo, vai falar da encarnação do Verbo, a partir da legítima aspiração humana à felicidade e os meios, ou melhor, o único meio de alcançá-la. $\mathrm{O}$ remoto christo não visa a afastar-se das Escrituras, mas estabelecer um outro modo de acesso às verdades nelas contidas, uma vez que, como salienta Viola (1996, p.208), o que é obtido pela razáo é profundamente conexo com o que é afirmado pela fé, de sorte a possibilitar uma conexão e colaboração entre a autoridade e a razão. Ao fim e ao cabo, as conclusôes, obtidas sola ratione, não deverão ir de encontro à autoridade, pois Anselmo deixa bem claro, desde o início da obra, que, embora a argumentação se constitua dialeticamente, há uma motivação bíblica que a impulsiona: é preciso dar as razóes da fé, como recomendado na Primeira Carta de Pedro (I Pd 3, 15).

No entanto, essas razões da fé são ofertadas, através do método sola ratione, não especificamente ao crente ou ao náo crente, mas à criatura racional como tal, comungue ela ou não da fé. Um tal esforço para compreender e explicitar a razoabilidade da fé assume, na perspectiva anselmiana, o caráter de um dever para o cristão que, convictamente, acredita nos profundos artigos da fé cristã e, se não é negligente, não se furta a dar as razôes da mesma. Um tal dever, porém, para ser efetivamente bem sucedido, necessita, consoante Anselmo, da firmeza na fé. 
O encadeamento lógico da razão, ou seja, o recurso às razóes necessárias, possibilita ao pensador o exercício de uma reflexão que pode ser chamada de filosófica, mesmo ao tratar de temas teológicos. A criatura humana, por ser imagem de Deus, é detentora de uma dignidade que lhe permite e incita a empreender um esforço de compreensão. O remoto christo do Cur Deus homo não quer desmerecer a ordem sobrenatural, mas valorizar a ordem natural. Assim compreendido, o esforço racional será benéfico ao próprio crente, porque indica a pertinência e a coerência de sua fé, proporcionando-lhe um estado de satisfação, um contentamento, propiciado pela razão e que antecipa, de um certo modo, ainda que de forma diminuta, a alegria plena, destinada à humanidade, desde sua criação. Inserida no plano maior da razão divina, a razáo humana é capaz de antecipar, de alguma maneira, a felicidade eterna. Esta parece ser uma tese de fundo que Anselmo deseja demonstrar, no Cur Deus homo. Não é mero acaso que um autor, tão cuidadoso com a clareza de seu texto, faça aparecer, nos dois primeiros capítulos do tratado - capítulos em que ocorre uma explanação acerca do método -, termos que remontam ao prazer e à satisfação, tais como placere $^{5}$, satisfactionem ${ }^{6}$, delectentur ${ }^{7}$.

Além disso, há também uma outra intenção: Anselmo entende que tratar sola ratione um tema tão relevante para os cristãos constitui uma excelente oportunidade para dialogar, no campo comum da razão, com aqueles que não creem. Diálogo, de fato, é a forma literária do tratado. Boso, um discípulo que acompanha Anselmo desde os tempos de Le Bec, na Normandia, é o interlocutor. Será Boso uma espécie de porta-voz daqueles que, ou não acreditam, ou não compreendem o que é afirmado pela fé cristá a respeito da redenção da humanidade, realizada pelo Filho de Deus feito homem.

Anselmo, sobretudo no Monologion, mas também no Proslogion, refletira sobre a trindade, sem, contudo, considerar a encarnação. Esse difícil tema vai receber uma primeira atenção na Epistola de Incarnatione Verbi, obra na qual critica Roscelino, autor que, ao aplicar à trindade seu entendimento acerca dos universais, conceberia as três pessoas divinas como substâncias separadas, destituídas de uma natureza comum, como se fossem três anjos ou três almas. Contra Roscelino, Anselmo defende a unidade substancial da trindade e explica por quais razóes apenas uma das pessoas assumiu a condição humana; justifica, igualmente, por que foi o Filho e não o Pai ou o Espírito

${ }^{5}$ Placere: CDH I,1,47,7; Placent: CDH I,1, 48,13; Placet: CDH I,1,49,25.

${ }^{6}$ Satisfactionem: CDH I,1, 47,10; Satisfacere: CDH I,1, 49,1 e CDH, I,2, 50,10-11.

${ }^{7}$ Delectentur: CDH I,1, 47,9. 
Santo que se fez carne e habitou entre nós. O Cur Deus homo, sem desprezar tais argumentos, procederá a um exame bem mais amplo das questóes que concernem à redenção da humanidade, destacando, ao mesmo tempo, a misericordiosa justiça divina e a singularidade do homem, enquanto criatura.

Resta ainda esclarecer, quanto ao método, a presença de dois planos argumentativos no Cur Deus homo: o da necessidade e o da conveniência. Nos primeiros capítulos, eles aparecem de modo distinto, a tal ponto que as primeiras razóes de conveniências apresentadas como justificativas para a encarnação são apontadas como acessórias, uma vez que, por si sós, não seriam suficientes para fundamentar as razóes da encarnação. No entanto, a partir do décimo capítulo do primeiro livro, Anselmo estabelece um princípio metodológico que indica, no caso específico de Deus, uma certa unidade entre o conveniente e o necessário, posto que, em relação a Deus, todas aquelas coisas que são convenientes passam a ser consideradas necessárias, desde que não haja nenhuma razão em contrário. Feitas essas considerações sobre o método, vejamos, então, de que forma Anselmo aplica à encarnação do verbo sua metodologia de investigar, fazendo uso tão somente da razão.

\section{A lógica da encarnação}

Não éo propósito do presente estudo apresentar uma exposição detalhada da argumentação de Anselmo. Mostraremos, contudo, os pontos fundamentais do Cur Deus homo, para podermos compreender qual é a perspectiva a partir da qual Anselmo compreende o homem. As objeçóes dos não crentes são o ponto de partida do autor. Elas residem, fundamentalmente, na ideia de que a encarnaçáo não seria compatível com a grandeza divina. A resposta, num primeiro momento, estrutura-se em argumentos de conveniência, tais como uma certa simetria entre a danação e a salvação humanas: em torno do pecado estava um homem, uma mulher e uma árvore; em torno da salvação estão um homem (o verbo encarnado), uma mulher (a virgem) e uma árvore (da qual foi feita a cruz). No entanto, Anselmo reconhece que a simples conveniência não dá conta da complexidade da questão. Mais tarde, voltará a falar de coisas que convêm a Deus, mas na perspectiva que referimos há pouco, consoante a qual, em Deus, o que é conveniente deve ser entendido como necessário, desde que não se faça presente nenhuma razão em contrário.

Admitindo-se que, de fato, o homem precisava ser remido, não poderia tal redenção ter ocorrido de um outro modo, por exemplo, através de um 
anjo ou de um outro homem, feito especificamente para tal fim? Anselmo, na mesma linha de Agostinho e inspirado em São Paulo ( $\mathrm{Rm} 5,12)$, entende que o pecado foi cometido por Adão; ora, em Adão está toda a natureza humana, inexistente antes dele e subsistente depois dele. O pecado, cometido por um homem e transmitido a todos os outros pela comum natureza, só pode ser superado por um descendente de Adão. Um outro problema, contudo, se apresenta: não há, entre os descendentes de Adão, quem esteja isento da culpa. Logo, parece impossível que a redenção ocorra. Disso resulta que o homem tem uma dívida e apenas ele deve pagá-la, mas não tem como fazêlo. A aparente aporia não será imediatamente resolvida, pois Anselmo deseja, primeiro, esclarecer algumas questôes preliminares, tais como os possíveis direitos do diabo.

Na tradição Patrística, alguns autores deixaram margem para um entendimento relativo aos direitos do demônio em relação ao homem, uma vez que Adão se entregou livremente ao pecado, sugerido pelo diabo. Há textos, inclusive, de Irineu ${ }^{8}$, Orígenes ${ }^{9}$ e Agostinho ${ }^{10}$, entre outros, que parecem dar guarida à tese. Essa concepção ainda persiste na época de Anselmo, visto que até alguns de seus discípulos pareciam estar convencidos dos supostos direitos diabólicos (cf. COUTIER, 1988). Gilberto Crispin, por exemplo, na Disputatio iudei cun christiano, composta em torno de 1092-1093, mesmo compartilhando de muitas teses anselmianas, não desconsidera os direitos do demônio; é bem verdade que, em seu tratado subsequente, Disputatio chrstiani cum gentili, nada menciona sobre este ponto, o que faz supor que seu autor, tendo tomado conhecimento do Cur Deus homo, possa ter mudado de opiniáo. Um outro discípulo, Raol de Battle, faz referência aos direitos do diabo, embora não saibamos o quanto ele conhecia a posição do mestre frente ao tema.

É importante salientar que Anselmo não vai totalmente de encontro à concepção dos Padres, pois ele não nega que Jesus Cristo tenha vencido o demônio. O que Anselmo náo aceita é que o diabo fosse detentor de eventuais direitos, pelo fato de o homem livremente ter acatado sua proposta pecaminosa. A interpretação anselmiana parece acentuar a pertença do homem a Deus e não ao diabo. Deus jamais abandonou o homem, apesar do pecado.

\footnotetext{
${ }^{8}$ Cf. Contra haereses V, 21, 1-3.

${ }^{9}$ Orígenes, p.ex, diz que "Satanás engoliu a isca da humanidade de Cristo e foi apanhado no anzol de sua divindade". Cf. Comentário sobre Mateus 13,28.
}

${ }^{10}$ Cf. De Libero Arbitrio III,10,31. 
O homem pode ter rompido com seu criador, mas o criador nunca deixou sua mais preciosa criatura entregue a si mesma ou entregue ao diabo, o que seria ainda pior. Assim sendo, Anselmo mostra, igualmente, o equívoco das interpretações que indicavam que Jesus Cristo, ao morrer, ludibriou Satanás, o qual, imaginando-se vitorioso quando da morte do filho de Deus, na verdade, estaria sofrendo, com a ressurreição do Cristo, a sua mais clamorosa e definitiva derrota. Para Anselmo, Deus não "enganou" o diabo, simplesmente porque Satanás não faz jus nem mesmo a um embuste. $\mathrm{Na}$ Meditatio redemptionis humanae, Anselmo é ainda mais enfático, declarando que Deus nem mesmo poderia enganar o demônio, já que a verdade jamais engana.

Quanto aos sofrimentos padecidos pelo filho de Deus, uma das grandes objeçóes dos não cristáos, Anselmo argumenta que Cristo escolheu, sem nenhum constrangimento, padecer pela salvaçáo dos homens. Sua morte se deu porque fez a vontade divina, com o intuito de fazer o que devia ser feito, isto é, observar a justiça; essa morte, contudo, foi causada pelos homens e, não por Deus. Afinal, o que Deus deseja é a restauração do gênero humano; ora, uma tal restauração exige do homem o pagamento de uma dívida a qual ele não tem com que pagar. Apenas o Deus feito homem seria capaz de tal pagamento. A reparação é exigida da humanidade pelo Pai. O mesmo pai permite que a dívida seja paga pelo Filho. Por mais paradoxal que pareça, o fato de Deus assumir a limitada condição humana e, por fim, padecer e morrer na cruz, como um indigno condenado, é portador de uma racionalidade, pois há uma lógica em toda essa circunstância. Para Anselmo, jamais a vontade divina é irracional, ainda que assim pareça aos olhos humanos. No caso dos sofrimentos padecidos pelo Deus feito homem, Anselmo esclarece que é preciso compreender que Jesus Cristo é verdadeiro Deus e verdadeiro homem. Trata-se de uma pessoa e duas naturezas. Ora, os sofrimentos decorrem da debilidade humana, assumida pela divindade. Não se trata, portanto, de um aviltamento da condição divina, mas de uma exaltação da natureza humana. O sujeito da redenção entregou-se ao sofrimento e à morte, sem que nada o constrangesse a tal, porque, não obstante os temores próprios da natureza humana, sua vontade acolheu integralmente a vontade divina, na plena realizaçáo da sua liberdade, entendida como o poder de conservar a retidáo da vontade pela retidão mesma, tal como fora definida a liberdade no De libertate arbitrii $(3,212,19)$.

A Anselmo não interessa apenas mostrar a possibilidade da redenção, mas quer, igualmente, discorrer sobre a sua necessidade. Com tal intuito, expóe, 
do décimo primeiro capítulo do Livro I até o sexto capítulo do Livro II do Cur Deus homo, os pontos fundamentais da sua "teoria da satisfaçáo". A teoria é bastante complexa; Nicola Albanesi (2002, p. 122), porém, sintetizou-a em forma silogística: Deus, ao criar o homem, destinou-o à felicidade; ora, o homem pecou, acarretando a perda da felicidade, a qual só poderá ser retomada com a remissão dos pecados; logo, é preciso que os pecados sejam remidos, a fim de que o homem possa, de novo, ser feliz.

Duas noções são fundamentais para a compreensão do que Anselmo está procurando mostrar: uma é o pecado do homem; outra é a honra divina. Ao elucidá-las, Anselmo traz à tona duas outras: justiça e misericórdia. Anselmo quer demonstrar que estas duas últimas noçôes não são contraditórias em Deus. À primeira vista, parece incongruente que um Deus que é poderoso não tenha o poder de perdoar o pecado do homem, a não ser com o sacrifício de um justo. Por outro lado, se Deus pode redimir o homem por um outro meio e não o faz, que justiça há nele?

A fim de esclarecer o problema, o autor do Cur Deus homo declara que pecar significa não dar a Deus a honra que Lhe é devida. O pecado dos primeiros pais foi, na verdade, contra a honra divina. Anselmo entende que a criação, por si mesma, torna o homem devedor da honra divina; trata-se, pois, de uma espécie de dívida ontológica fundamental. O honrar a Deus é característico da criatura racional. Para isso foi feita e é o que deve fazer, por isso, a única atitude cabível, em relação ao criador, é a sujeição. Sujeitar-se a Deus outra coisa não é senão conformar livremente a própria vontade à vontade divina. Aí reside o honrar a Deus. No entanto, tudo está inserido num plano amoroso e uma tal sujeição, o honrar a Deus, nada mais é do que amar e ser amado. Na perspectiva anselmiana, "o lugar do homem no cosmos" é o amor. O homem foi feito por amor e feito para amar. É nessa ótica que precisa ser compreendida a "honra" devida a Deus, por parte do homem, e que é fundamental no Cur Deus homo. Não se trata da atitude de vassalagem do servo em relação ao seu senhor ${ }^{11}$, pois o que fundamenta a concepção de Anselmo é muito mais do que um mero dever,

\footnotetext{
${ }^{11}$ Greshake, em Erlösung und Freiheit, ao acentuar a ideia de honra divina no tratado de Anselmo, enfatiza que a teoria da satisfação tem como referência o direito germânico que funda o direito feudal, com a ideia de fidelidade entre vassalo e senhor. Greshake, entretanto, entende que a intenção de Anselmo é mostrar a bondade de um Deus que exige a reparação da honra ofendida, náo como um homem, mas em vista da recomposição da ordem do mundo, expressão da justiça divina. Uma interessante síntese da teoria de Greshake, bem como das principais leituras e interpretaçôes sobre a teoria de Anselmo, pode ser encontrada na primeira parte da obra de Nicola Albanesi, Cur Deus homo: la logica della redenzione. Roma: PUG, 2002.
} 
mas o amor. De acordo com Corbin (1997), quando Anselmo alude a dever, a submissão, isso precisa ser entendido na perspectiva de um dom: submeter a minha vontade a Deus significa reconhecer que tudo devo a Ele e me alegro com Ele e com meu próximo pelo dom recebido. Assim, fica estabelecida uma relação que náo tem outra intenção a não ser o amor gratuito e, por conseguinte, feliz. Pois bem, ao pecar, o homem instaurou uma desordem no mundo criado. Uma tal desordem provoca uma dupla incompatibilidade, pois vai de encontro tanto à grandeza divina quanto à felicidade humana. Ao pecar, o homem vê-se na condição de ter de enfrentar as penas que daí decorrem. Não se trata, conforme Anselmo, de um castigo divino, pois a pena, decorrente do pecado, é a perda da condição original, é um mal que não foi dado por Deus, mas um mal que o homem fez a si mesmo. Exposto o problema, é preciso, entáo, apontar para a solução. Anselmo apresenta possíveis alternativas de superação do problema: Deus não poderia, simplesmente, perdoar a dívida, já que o homem não tem mesmo como pagá-la? Um tal perdão seria mesmo perfeitamente coerente com o que é dito na oração do "Pai Nosso", porque, se devemos perdoar os pecados dos que nos têm ofendido, também Deus deveria perdoar os pecados daqueles que Lhe ofenderam. Contudo, um perdáo sola misericordia, consoante Anselmo, seria incompatível com a justiça divina, além de não contribuir para que o homem pudesse aprender com os erros cometidos. Não bastasse isso, um tal perdão impossibilitaria a felicidade plena do homem, já que ela seria alcançada a partir de sua impotência, o que não favoreceria a dignidade da criatura racional.

Não é possível que Deus abra mão da justa ordem que Ele mesmo estabeleceu. Ora, Deus é não apenas justo, porém, é a justiça suprema, é também a plena misericórdia. No Monologion, Anselmo havia mostrado que não há sobreposição de atributos na divindade, por isso, em Deus, justiça e misericórdia são o mesmo. Depreende-se que é por ser misericordioso que Deus quer o restabelecimento da justiça. A consequência é que a dívida do pecado deve ser paga pelo homem, pois foi o homem quem pecou: Adão pecou e um descendente de Adão deve resgatar a humanidade. $\mathrm{O}$ resgate, todavia, precisa ser proporcional ao mal cometido, o que faz surgir um grande problema: o que pode o homem dar a Deus que já não Lhe seja devido? Nenhum homem é capaz de ofertar a Deus aliquid maius.

Anselmo conduz o diálogo de forma a explicitar uma necessidade que se defronta com uma impossibilidade: o homem deve, mas não pode pagar sua dívida; apenas um Deus homem poderia obter algum mérito capaz de satisfazer a honra divina e pagar a dívida contraída pela humanidade e que a impede de 
ser feliz. Anselmo entende ter demonstrado, sola ratione, a necessidade lógica da encarnação, de maneira que apenas um insipiens poderia negá-la. O uso de expressôes tão próximas do Proslogion não é mera coincidência: Anselmo quer acentuar a singularidade e a gravidade de um pecado cometido contra Aquele que é, ao mesmo tempo, id quo maius cogitari nequit e sit benignus, ut nibil benignus cogitari queat. $\mathrm{O}$ autor do Cur Deus homo está a preparar o terreno para a grande conclusão de sua obra: só um gesto de singular misericórdia e justiça, um gesto de uma tal magnitude que maior não possa ser pensado, será capaz de livrar o homem do mal e da morte, para destiná-lo à felicidade. Os últimos capítulos da obra tratam, precisamente, do modo como se realiza a redenção.

O sétimo capítulo do livro II é particularmente interessante, porque Anselmo reafirma o caráter ontologicamente perfeito do sujeito da redenção; o Deus homem é perfectum Deum et perfectum hominem. O verbo, ao se fazer homem, não abdica de sua condição divina. De fato, na Trindade, há uma pluralidade de pessoas, unificadas em uma natureza única, a natureza divina. No verbo encarnado, porém, a natureza divina está presente, juntamente com a natureza humana. A unidade substancial, aliada à dualidade de naturezas, as quais não se sobrepóem, nem se misturam, é a condição necessária e insubstituível para que ocorra a justificação do homem. Toda a argumentaçáo de Anselmo vai ao encontro das resoluções do Concílio de Calcedônia (451), o qual definia Jesus Cristo como sendo perfeitamente Deus e perfeitamente homem, detentor de uma alma racional e de um corpo, sendo consubstancial ao Pai, conforme a divindade, e consubstancial aos homens, conforme a humanidade. Há, pois, em Jesus Cristo, duas naturezas (humana e divina) que não se confundem, não se transformam e não se separam.

Para garantir a razoabilidade e necessidade da encarnação, em conformidade com sua linha de investigação, Anselmo enfatiza a plena identificação do verbo com a raça de Adão e, para tal, mais uma vez, realça uma simetria entre a origem do mal e sua superação. Assim como na origem do pecado, também na sua superação, há um o envolvimento ativo de uma mulher. O novo Adão nasce de uma virgem, uma vez que Deus pode fazer nascer de diversos modos, e enfrenta a morte, de forma livre e consciente. Seu sacrifício acaba por desvelar à humanidade decaída a essencial condição humana; ao morrer e ressuscitar, demonstra que a morte não pertence à essência do homem; é bem verdade que Adão morreu e o homem é mortal, 
mas a mortalidade é relativizada, pois é apresentada como uma consequência do pecado e não como um atributo essencial da humanidade.

Entretanto, se tal é a condição do homem, por que o Deus feito homem teve de enfrentar a morte? Não é absurdo que o autor da vida tenha que morrer? Como já frisamos, o que Anselmo quer evidenciar é a livre escolha: tal morte foi aceita de maneira plenamente livre e consciente de todas as implicaçóes. Absolutamente inocente, isto é, completamente isento do pecado, uma vez que sempre orientou sua vontade para a justiça, o verbo encarnado poderia não morrer. Ao entregar sua vida, no entanto, satisfaz adequadamente a dívida da humanidade, oferecendo a Deus aliquid maius.

Um dos pontos mais importantes da reflexão suscitada pelo Cur Deus homo é a questão da liberdade, na sua relação com a superação do mal e do pecado. A entrega da vida foi realmente livre, visto que o sujeito da redenção sempre foi sabedor de todas as implicaçóes de seu gesto, inclusive o sofrimento e a dor. O homem é, essencialmente, livre; é bem verdade que a queda dos primeiros pais obscureceu tal liberdade, pois o homem se tornou escravo do pecado; o sujeito da redençáo, ao assumir livremente a vontade divina, permite que a humanidade recupere a liberdade inerente à sua dignidade.

O zelo argumentativo de Anselmo conduz a uma questão de difícil resolução: como o sujeito da redenção pôde ser tirado da massa pecadora e não ser, também ele, atingido pelo pecado? Pôde, dirá Anselmo, por ter nascido de uma virgem que foi preservada do pecado original, em vista do nascimento do Deus feito homem. A explicação para tal excepcionalidade não é, em si mesma, o ponto mais denso da argumentação: os efeitos da redenção atingem todos os homens do presente, passado e futuro, portanto, a virgem foi preservada do pecado, antecipadamente, em função dos méritos da entrega da vida de seu filho pelo bem da humanidade. O que interessa realmente a Anselmo é ressaltar a liberdade, por isso vai além e pergunta: terá sido realmente livre a morte do homem-Deus? Náo deveria ele, necessariamente morrer, uma vez que deve sua existência - encarnado no seio da virgem, preservada do pecado, tendo em vista os méritos da futura morte do filho - precisamente em função da morte que devia sofrer?

Anselmo procura resolver o problema distinguindo dois tipos de necessidade: uma praecedens e outra sequens. A necessidade precedente é a causa eficiente: é o caso do movimento do céu; o céu se move porque é necessário que se mova, ou seja, há uma necessidade natural que determina 
tal movimento. A necessidade subsequente, por outro lado, é criada pela coisa mesma: é o caso de alguém que está a falar: ninguém impingiu que falasse, contudo, a partir do momento em que fala, é impossível não falar. A necessidade precedente sempre leva a uma necessidade subsequente, mas nem sempre uma necessidade subsequente existe em função de uma precedente. Com tal distinção, Anselmo entende ter mostrado que a morte redentora é uma necessidade subsequente, não imposta por qualquer constrangimento, mas unicamente como consequência de uma vontade inteiramente livre. Com isso, Anselmo preserva o caráter absolutamente livre da morte redentora do verbo encarnado.

Assim, apresenta a morte de Cristo como um plus in infinitum, uma demonstração de tal modo amorosa que maior não pode ser pensada. Tal ato supererrogatório resulta no perdão dos pecados de todos os homens do presente, passado e futuro, inclusive os carrascos que provocaram a morte injusta do verbo encarnado e, até mesmo, os pecados dos primeiros pais. A redenção é, por assim dizer, efetivada, na medida em que o filho transfere à humanidade encurvada pelo pecado, tal como é descrita no Proslogion, os méritos da entrega da sua vida. Anselmo, no final do Cur Deus homo, entende ter mostrado, com clareza, que a lógica da encarnação revela o que, num primeiro momento, poderia parecer impossível: a conciliação entre a justiça e a misericórdia divinas.

\section{O LUgAR do hOMEM No PLANO Divino}

No primeiro livro do Cur Deus homo, nos capítulos 16 a 18, Anselmo, de uma certa maneira, deixa de lado o tema da redenção humana, operada pelo verbo, para tratar da queda dos anjos e sua substituição pelos homens eleitos, conforme uma certa interpretação do texto do evangelho de Lucas, 20, 35-36, onde se lê que aqueles que forem dignos da ressurreição serão semelhantes aos anjos, mesmo porque os homens eleitos, da mesma forma que os anjos bons, terão uma mesma função, qual seja, o louvor divino. Anselmo quer ressaltar que os homens retos serão como os bons anjos, quando, finalmente, a restauração do plano divino for levada a cabo. No entanto, o que podemos observar é que Anselmo, ao tratar dos anjos, acaba por evidenciar a singularidade do homem, na ordem da criação.

Anselmo argumenta a partir de uma certa estética celeste: teria sido o homem criado, unicamente, para completar o número dos anjos caídos, 
tendo em vista a harmonia da cidade celeste? Havia, de fato, quem atribuísse essa função ao homem: a cidade celeste seria composta por anjos e homens, sendo que os últimos estariam em igual número dos anjos caídos, a fim de restabelecer a harmonia perdida com a queda dos anjos rebeldes.

De acordo com Anselmo, o número das criaturas racionais destinadas à beatitude da contemplação divina foi por Deus determinado desde toda a eternidade. Destarte, os anjos maus estavam, evidentemente, incluídos no número, por Deus estipulado, para compor a cidade celeste. Como eles não permaneceram na justiça, afastaram-se, de modo irrecuperável, da felicidade eterna. Tal afastamento, evidentemente, não era desejado por Deus. O que resulta de tal desobediência é o surgimento de um déficit numérico na cidade celeste que deve ser preenchido, porque o número por Deus estabelecido é perfeito e a harmonia celeste náo pode ser comprometida. Tal substituição não poderia ser feita por outros anjos, surgidos, especialmente, para esse fim? Anselmo acredita que náo, uma vez que criaria uma situação inusitada: os supostos novos anjos deveriam ser iguais aos anjos maus, antes da queda. Pois bem, ao substituírem os caídos, eles saberiam, de antemão, da situação daqueles que estavam sendo substituídos. Ora, a perseverança deles na justiça deveria ser atribuída à sua vontade reta ou ao medo do castigo, já que seriam sabedores do infeliz destino dos outros? Por conseguinte, parece razoável supor que os homens eleitos substituirão os anjos pecadores, restabelecendo, nesse sentido, a perfeita harmonia numérica da cidade celeste.

Apesar desse entendimento, Anselmo, no início do décimo - oitavo capítulo do primeiro livro -, aponta para uma outra possibilidade, qual seja, a de que os anjos, mesmo antes da queda, não constituíam um número perfeito e, nesse caso, seria necessário completar, com os homens eleitos, tanto aquele número que faltava (mesmo antes da queda dos anjos) como também o número que foi perdido (pela queda dos anjos), a fim de atingir a perfeição numérica. Conclui, então, que o homem não é apenas um substituto dos anjos, mas a criatura humana foi criada por si mesma - pro se ipsa ibi facta est -, de tal forma que, mesmo que nenhum anjo tivesse caído, ainda assim, os homens teriam seu lugar garantido na perfeição da cidade celeste. $\mathrm{O}$ número de homens eleitos, portanto, será maior do que o de anjos caídos, pois, se assim náo fosse, a alegria dos primeiros seria devedora da infelicidade dos últimos, o que não condiz com a harmonia da cidade celeste. Assim sendo, fica resguardado o papel singular do homem na cidade céu, de tal maneira que 
Anselmo pode dizer que haverá procriação até que se complete o número dos homens eleitos, e, isso feito, cessará a geração dos homens neste mundo.

É interessante que consideremos as razões dessa discussão proposta por Anselmo. O tema dos anjos caídos foi por ele investigado no De casu diaboli, mas é retomado no Cur Deus homo, de um tal modo que se ajusta, harmoniosamente, ao tema central da obra, que é a elucidação e fundamentação das razões pelas quais Deus se fez homem. Ao abordar a queda dos anjos, Anselmo, para além de uma certa contabilidade soteriológica, pôde mostrar que o homem ocupa um lugar único e importante na ordem da criação. E, justamente por isso, a encarnação do Filho tem um sentido absolutamente fundamental. É muito interessante a observação de Varisco (1999), ao sublinhar que, se o homem tivesse sido criado apenas para substituir os anjos rebeldes, Cristo se teria encarnado para remediar o pecado do homem; porém, o homem, por sua vez, existiria apenas para remediar o pecado dos anjos. Em tal caso, a vinda do Filho nada mais seria do que um remédio de um remédio, demonstrando uma imperfeição na obra divina. O sentido fundamental, eficaz e insubstituível de Deus ter assumido a condição humana é que o homem tem um lugar singularíssimo no plano absolutamente justo e, por conseguinte, harmônico da criaçáo de todas as coisas por parte de Deus; ou seja, é a dignidade e a singularidade do homem que dá sentido à encarnaçáo ou, como evidencia Xavier (1999, p. 90-91), a dignidade do homem transparece como a razáo maior da necessidade da encarnação, já que Deus, que não é apenas justo, mas é a justiça, não deixaria uma imperfeição na cidade celeste, cidade a qual caracteriza a ordem final da criação.

Tais consideraçóes de Anselmo possibilitam e até mesmo ensejam uma leitura antropológica do Cur Deus homo. O drama humano, tal como é vislumbrado por Anselmo, está indissociavelmente relacionado com a liberdade. Não seria melhor o homem não ser livre? Conforme Anselmo, a liberdade, por ser isenta de todo e qualquer impedimento, é um bem táo grande que, em vista dele, vale a pena correr o risco do pecado (cf. ROGERS, 2008, p.91). A verdadeira liberdade, no entanto, não significa, para Anselmo, uma escolha entre pecar e não pecar. Se assim fosse, Deus e os bons anjos não seriam livres, pois eles não podem pecar. Lembremos que, consoante Anselmo, a liberdade é o poder de conservar a retidão da vontade pela retidão mesma ${ }^{12}$. Essa definição mostra como, na concepção anselmiana, a alternativa entre pecar

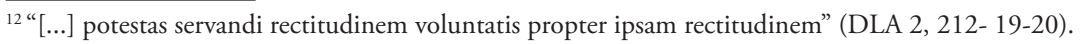


ou não pecar está fora do âmbito da liberdade, porque esta não comporta, de modo algum, o poder de pecar.

A liberdade é algo próprio da natureza humana, uma natureza que é boa e que não sucumbe ao pecado original, ainda que o homem tenha perdido a retidão original. Contudo, não estar reto não significa que não se possa erguerse, já que isso é próprio do homem e dele não pode ser tirado. O que Anselmo quer dizer, em última análise, é que o homem foi criado bom e livre, razão pela qual foi, é e sempre será, essencialmente, bom. Sua natureza é boa, embora o pecado não permita que se vislumbre, na totalidade, uma tal natureza.

A redenção trazida pelo Deus-homem não exime a criatura racional do esforço de conservar a retidão da vontade pela retidão mesma. A beatitude é, sem dúvida, a consequência da vida justa, mas viver retamente implica querer a retidão por si mesma, isto é, desinteressadamente. Anselmo, por certo, não ignora a dificuldade enfrentada pelos homens que, mesmo querendo o bem, acabam por ceder ao mal. Mesmo assim, reafirma no De libertate arbitrii que a vontade reta nunca é abandonada, a não ser voluntariamente. Coisas há que o homem é forçado a fazer, apesar de contra a sua vontade: um homem pode ser amarrado, mesmo não querendo; um homem pode ser torturado, mesmo não desejando a tortura; um homem pode até ser morto, contra a sua vontade, entretanto, não é possível que um homem queira contra a sua vontade, pois é impossível que queira, querendo não querer. Mesmo nas trevas ou tendo os olhos vendados, o homem não perdeu a capacidade de ver, ainda que não esteja fazendo uso dela. Tal capacidade é própria dele e não lhe pode ser tirada. Com esse exemplo, Anselmo quer ressaltar que, ainda quando falta a retidão, o homem náo perde a capacidade de saber o que deve ou náo fazer, ou seja, ele não perde a capacidade de saber o que é reto e, uma vez sabendo, é livre para observar a justiça e, portanto, sempre é possível resistir ao mal, porque o mal e a morte, que é sua consequência, não pertencem à natureza humana.

Pois bem, o verbo encarnado, ao fazer a vontade amorosa do pai até o fim, de modo livre, revela à humanidade que é possível observar a retidão da vontade por si mesma; de fato, sendo ele Deus, náo podia desejar nenhuma recompensa para si, pois nada a ele faltava. No verbo encarnado, obediente até a morte e morte de cruz, está exposto à humanidade o paradigma da conformidade à justiça, à verdade e à liberdade. Em última instância, é possível dizer que o verbo aceitou o sofrimento e a morte porque quis, isto é, por ter orientado plenamente sua vontade à vontade divina. Anselmo declara, no $D e$ casu diaboli, que o diabo pecou, ao fim das contas, porque quis. Nos dois casos, 
percebe-se o papel primordial que Anselmo confere à vontade e sua relação com a virtude. Com o pecado, o homem ficou impossibilitado de imitar a virtude divina; o verbo feito homem vem mostrar ao gênero humano o ideal da virtude. Apesar de um tal modelo, a humanidade, mesmo remida, não é capaz de, por si só, sem uma íntima relação com ele, segui-lo em plenitude. A humanidade pode olhar para aquele Deus que se fez perfeitamente homem, sem deixar de ser perfeitamente Deus, a fim de indicar aos homens o caminho da perfeição, pois a humanidade é chamada a fazer parte de um projeto amoroso de tal grandeza e dignidade que não pode ser pensado maior.

\section{ConClusóEs}

O otimismo é uma marca da obra de Anselmo. Seus escritos apontam sempre para a possibilidade de dizer o inefável (cf. GILBERT, 1984) e dizê-lo sola ratio. $\mathrm{O}$ otimismo gnosiológico, tâo presente em obras como o Monologion e o Proslogion, se traduz num otimismo antropológico, no Cur Deus homo. Ao apontar a misericordiosa racionalidade divina como a solução plenamente eficaz e definitiva para o problema do mal, Anselmo garante ao homem a real possibilidade de ir ao encontro da felicidade. Não se trata apenas de uma manifestação de fé, fundada na esperança cristá. É, evidentemente, também isso, porém, o que singulariza a ética e a antropologia anselmianas é que uma tal esperança, sem deixar de ser plenamente cristá, jamais se radica num credo quia absurdum, uma vez que o homem, com seus erros e virtudes, bem como toda a criação, ainda que gema em dores de parto (cf. Rm 8, 22), estão radicados num Logos.

O método utilizado pelo autor - remoto christo - vai, precisamente, em tal direção: a Anselmo não importa a vida pública de Jesus. Não seria interessante aludir a seus ensinamentos e açôes, a fim de mostrar sua perfeita retidão, alicerçada na inclinação de sua vontade à vontade do Pai, a partir dos seus atos e palavras? É provável que sim, mas Anselmo prescinde de tais fatos; aceitá-los seria abdicar do remoto christo. A necessidade da encarnação - com suas consequências principais, quais sejam, a superaçáo do mal e a possibilidade da felicidade para o homem - é apresentada num contexto de racionalidade que extrapola quaisquer circunstâncias históricas e religiosas, para ir ao encontro de algo bem mais amplo e ambicioso, qual seja, a razão. Anselmo parece querer mostrar que a felicidade é o destino não do cristáo, especificamente, mas da criatura racional. Trata-se de uma verdade a qual 
pode ser compreendida racionalmente, ainda que a adesão às suas implicaçóes envolva bem mais do que uma compreensão lógica, porque é preciso uma vontade reta e, sobretudo, um desejo amoroso.

Anselmo, leitor atento do evangelho de João, percebe que o verbo que se fez homem, ou seja, aquele que veio para os seus, mas não foi compreendido, é o Logos (cf. Jo 1, 18), presente na criação, através do qual todas as coisas, incluindo o homem, foram sendo feitas, à medida em que eram ditas pelo Verbo criador. Pois bem, o que resulta de todo o conjunto argumentativo do Cur Deus homo é que a criação e, de modo especial, o homem, é a demonstração de uma reta ordem, isto é, uma justa ordenação que é fruto de uma razão divina. A lógica da encarnação decorre da lógica da criação, em que todas as coisas, inclusive e especialmente, o homem, são per aliud, mas esta proveniência não é outra senão uma boa razão, pois tudo que decorre do verbo criador é muito bom. Tal racionalidade da criação que não deseja, embora permita, a ruptura do homem com o fundamento e razão de seu ser, aponta para a necessidade da encarnação, visto que Deus é não só a origem, mas também o fim do homem.

Por que, afinal, Deus se fez homem? A resposta, deduzida racionalmente no Cur Deus homo, está contemplada, perfeita e sucintamente, na Meditatio redemptionis humanae: Deus assumiu a humanidade porque essa era a sua vontade, uma vontade que é sempre boa ${ }^{13}$. O Cur Deus homo está a dizer, fundamentalmente, que o Logos que origina e fundamenta todas as coisas não sucumbe ante a ruptura. Anselmo não minimiza nem relativiza a gravidade do pecado original, no entanto, a estrutura ontológica do homem é imperecível. É por tal razão que o homem, apesar de tudo, permanece e sempre permanecerá essencialmente bom, pois boas são as coisas que provêm daquele cujo nome não pode ser pensado maior. A encarnaçáo do verbo recompóe o homem encurvado, de sorte que Anselmo entende ser a obra da redenção maior do que a obra da criação. $\mathrm{O}$ logos fundante do homem e de toda a criação é mais forte que o pecado e a morte e radica-se numa verdade inamissível. Assim compreendido, não nos parece que o Cur Deus homo possa ser a expressão de um Deus sanguinário ou revelador de uma concepção feudal de justiça, como acenam algumas interpretaçóes críticas. Anselmo, na verdade, elabora um encadeamento de razóes necessárias que possibilita mostrar a crentes e incrédulos que o verbo se fez homem para completar o sentido de uma obra amorosa, de tal modo grandiosa, que maior não pode ser pensada. A razão que sublinha

13 "Sola igitur voluntate, et quoniam voluntas eius semper bona est, sola hoc fecit bonitate". (Meditatio redemptiones humanae $86,62-63$ ). 
a necessidade de um Deus que se faz homem é diminuto reflexo, mas nem por isso desprezível, de uma Razão maior que aponta para um sentido, não totalmente compreensível, para o drama humano e para a presença do mal no mundo. Anselmo é, inegavelmente, um pensador cristão que, ao manifestar suas profundas convicções num Deus que é amor e que é Logos, empreende um esforço racional para dizer, sola ratione, que Deus se fez homem para mostrar à humanidade que a liberdade, a retidão e a verdade são a origem que o constitui e o fim último da sua esperança. Eis o homem!

VASCONCELLOS, Manoel. An anthropological reading of Anselm's Cur Deus homo. Trans/Form/Ação, Marília, v. 37, n. 3, p. 111-130, Set./Dez., 2014.

\begin{abstract}
This study aims to analyze St. Anselm's Cur Deus Homo from an anthropological perspective. After analyzing the method used in this work and reviewing its basic argumentation, it can be seen that Anselm reveals a perspective according to which human nature is essentially good. This nature, even when shaken, does not succumb to original sin. Freedom and the loving design of the originating Logos underlie the Anselmian conception of man and his nature.
\end{abstract}

KEY WORDS: Man. Freedom. Original sin.

\title{
REFERÊNCIAS
}

\section{a) Obras de Anselmo:}

Opera Omnia - S. Anselmi Cantuariensis Archiepiscopi - ad fidem codicum recensuit Franciscus Salesius Schmitt. Edimburgi: Thoman Nelson et Filios, 1946-1951.

L'oeuvre de Saint Anselme de Cantorbery. Sous la direction de Michel Corbin. Paris: Cerf, 1986ss. Textos da edição de F. S. Schimitt com introdução, tradução e notas por M. Corbin e outros.

Perchè un Dio Uomo. Versione, introduzione e note a cura di Dario Cumer. Roma: Edizione Paoline, 1965.

Porquoi Dieu S'est Fait Homme. Texte latin, introduction, bibliografhie, traduction et notes para René Roques. Paris: Cerf, 2005. 


\section{B) Outras obras:}

ALBANESI, Nicola. La logica della redenzione. Roma: PUG, 2002.

ARDUINI, Maria Lodovica. 'Sola ratione procedamus' (Cur Deus homo, 1, 20). Tradizione e novità nel segno semantico anselmiano: 'Sola Ratione', le fonti I: Sant'Agostino”. Rivista di Filosofia neo-scolastica, v. 83, n. 1/2, p. 90-141, 1991.

CORBIN, Michel. La Pâque de Dieu: quatre études sur S. Anselme de Cantorbéry. Paris: Cerf, 1997.

COUTIER, J.F Iustitia Diaboli: Anselme, Gilbert Crispin et Rodulfus Monachus. In: CONGRESSO ANSELMIANO INTERNAZIONALE, 1988, Roma. Cur Deus homo: atti del congresso... La cura di Paul Gilbert, H. Kohlenberger, E. Sallmann. Roma: Centro Studi S. Amselmo, [19-]. p. 235- 260.

GILBERT, Paul. Dire l'ineffable, lecture du Monologion de Saint Anselme. Paris: Lethiellieux, 1984.

GRESHAKE, G. Erlsösung und Freiheit. Zur Neuinterpretation der Erlösungslehere Anselms von Canterbury. In: DERS, Gottes Heil. Glück des Menshen. Theologische Perspektiven, Freiburg u. a., 80, 80-104, 1983.

MACEDO, J. M. C. Anselmo e a astúcia da razão. Porto Alegre: EST, 2009.

ROGERS, Katherin. Anselm on Freedon. Oxford: Oxford University Press, 2008.

VARISCO, Novella. Dal cur homo al cur Deus homo: un percorso sulla via della consapevolezza. In: CONGRESSO ANSELMIANO INTERNAZIONALE, 1988, Roma. Cur Deus homo: atti del congresso... La cura di Paul Gilbert, H. Kohlenberger, E. Sallmann. Roma: Centro Studi S. Amselmo, [19-].

VIOLA, Coloman. Authority and reason in St. Anselm's life and thought. In: LUSCOMBE, D. E.; EVANS, G. R. (Eds.). Anselm Aosta, Bec and Canterbury. Sheffield: Sheffield Academic Press, 1996. p.172-208.

XAVIER, Maria Leonor. Necessidade e historicidade, razóes de conveniência na teologia de Santo Anselmo. Itinerarium, Lisboa, v. 37, n. 141, p. 353-357, 1991.

Recebido em: 03/09/2014

Aceito em:24/09/2014 